\title{
Forensic Project Management: An Exploratory Examination of the Causal Behavior of Design-Induced Rework
}

\author{
Peter E. D. Love, David J. Edwards, and Zahir Irani
}

\begin{abstract}
The determination as to why projects fail to meet planned schedule, cost, and quality parameters is a leitmotiv within the construction, engineering, and project management literature. Yet, the interrelatedness and behavior of key factors that influence these project performance indicators, particularly regarding design-error-induced rework, have received limited academic examination. Design-induced rework has been reported to contribute more than $70 \%$ of the total amount of rework experienced in construction and engineering projects. To address this situation, a forensic management approach to determining how and why rework occurred in a commercial construction project is undertaken. Using findings from this case study along with knowledge from the literature, a systemic causal model for design-error-induced rework is developed. Underlying behavioral dynamics that contributed to design errors (principally related to the management of the design documentation process) were modeled and simulated using system dynamics. The results of such an analysis yield insights about architectural and engineering professionals' decisionmaking and work practices that can influence the occurrence of design errors. The mitigation of design-induced errors would significantly reduce the amount of rework that architectural and engineering firms experience. This would bring with it greater profitability for such firms and improved project performance parameters (schedule, cost, and quality).
\end{abstract}

Index Terms-Design, errors, learning, rework, system dynamics.

\section{INTRODUCTION}

D ESIGN-INDUCED rework has been found to contribute to $70 \%$ of the total amount of rework that is incurred in projects [13], [42]. Having to unnecessarily repeat activities or processes that were incorrectly implemented the first time within a project can adversely affect the profitability, performance, and reputation of those organization(s) involved; as well as a project's organizational and social fabric [46]. This is particularly the case in construction projects, where rework, which invariably results from design errors or design changes (e.g.,

Manuscript received October 1, 2004; revised May 1, 2005 and June 1, 2006. Review of this manuscript was arranged by Department Editor J. K. Pinto. This work was supported by the Australian Research Council under Grant DP0453258.

P. E. D. Love is with the Cooperative Research Centre for Construction Innovation, Department of Construction Management, Curtin University of Technology, Perth, WA, 6845, Australia (e-mail: p.love@curtin.edu.au).

D. J. Edwards is with the Off-Highway Plant and Equipment Research Centre (OPERC), Department of Building and Civil Engineering, Loughborough University, Loughborough, LE11 3EJ, U.K. (e-mail: D.J.Edwards@lboro.ac.uk).

Z. Irani is with the Brunel Business School, Brunel University, Uxbridge, UB8 3PH, U.K. (e-mail: Zahir.irani@brunel.ac.uk).

Color versions of one or more of the figures in this paper are availale online at http://ieeexplore.ieee.org.

Digital Object Identifier 10.1109/TEM.2008.919677 client-initiated), has been acknowledged as being the primary factor contributing to time and cost overruns [43]. Such design changes are a frequent occurrence within construction [18], [32]. They can generate costly ripple effects leading to delay and disruption throughout the entire project supply chain [3].

Projects may often appear to be going smoothly until nearing completion, when errors made during their formative stages are discovered necessitating costly rework [17], [27], [43], [75]. Of more importance is that design errors, if undetected, may lead to civil, geotechnical, or structural failures, which can have catastrophic consequences including severe injuries and even fatalities [11], [12], [14], [24], [52], [68]. "High-profile" construction and engineering failures that have led to fatalities include the Tay Bridge, Teton Dam, Three Mile Island, Chernobyl, West Gate Bridge, Kansas Hyatt Regency, and more recently, the Paris Charles de Gaulle International Airport [7], [29], [38], [59], [62], [68].

Such occurrence of catastrophic failure typically triggers a forensic investigation of engineering and management practices, not least to determine how and why the event happened and what could have been done to prevent it. The information obtained from a forensic investigation can be used to stimulate learning and guide future decision or policy-making, as well as initiating process improvement activities. However, forensic investigations rarely take place when the project failures do not make headlines (inasmuch as they are far less dramatic); although even these "minor" failures tend to result in productivity losses, cost and schedule overruns, and contractual claims. Even when a project is deemed to be successful, the likelihood of design errors and rework occurring is very high, and so forensic examinations are still needed to be undertaken if performance is to be improved.

Notwithstanding widespread availability of lessons learned from project failures and successes and resulting technological advancements, design errors still continue to plague construction projects. This is because many design and construction organizations often focus on "preparing the next bid and project," and as such, do not allocate adequate time for reflection, which is a critical part of any learning process [49]. Moreover, the increasing cost and schedule demands being imposed by clients on architectural and engineering (design) consultants, often results in limited attention being given to design verification and review processes [45]. One school of thought regarding the latter is that this is a symptom of procuring professional services through competitive bidding [19]; which often results in clients encountering incomplete (or erroneous) design-related documentation. 
This may then be issued to contractors as a basis upon which to compile their tenders. Typically, the errors contained within such documentation are not detected until operations begin on-site and, as a result, they adversely impact the management, planning, and procurement of the project. Furthermore, design errors can contribute to engineering and plant operator reliability problems, which have been found to adversely impact safety [34].

To investigate these problems of "design-induced rework," this paper presents a forensic management approach, based upon the methodology of system dynamics, to determine how and why rework occurred in a commercial construction project. The key factors that contribute to design-error-induced rework are identified from a review of the normative literature and used to produce an influence diagram, which is used as the basis for examining rework in a case study project. The findings from the case study project are used to modify the proposed influence diagram and produce a causal model of design-error-induced rework. The key issues identified from the case study are then modeled and simulated to gain an understanding of the complex interactions and consequences of rework. Mitigation of designinduced errors will reduce the amount of rework that design firms experience, and thus, improve their overall profitability and the performance of the projects that they are involved with.

\section{ERROR-INDUCED REWORK IN PROJECTS}

\section{A. System Dynamics and Forensic Project Management}

System dynamics is an appropriate modeling technique for analyzing or managing complex processes, which involve changes over time and are dependent on the feedback, transmission, and receipt of information [62]. System dynamics is defined as "a rigorous method for qualitative description, exploration, and analysis of complex systems in terms of their processes, information, organizational boundaries, and strategies; which facilitates quantitative simulation modeling and analysis for the design of system structure and behavior" [77]. System dynamics also "offers a rigorous method for the description, exploration, and analysis of complex project systems comprised of organizational elements, the project work packages and environmental influences" [65]. The method has been used as a project postmortem diagnosis tool [16], [76]. Consequently, and in this specific context, it can be used to provide managers with the necessary insights about the interdependencies and behavior between key variables that can contribute to rework so that learning and process improvements can be made to future projects [17].

Within this paper, the term forensic project management is coined to denote "the activity of determining the causal mechanisms that contribute to unsatisfactory project performance related to error-induced rework." The term forensic has a legal connotation relating to science used in the investigation and establishment of facts or evidence in a court of law. System dynamics has been used on several occasions to support legal proceedings with respect to delays and disruption claims in projects [3], [16]. For the purposes of this paper, the term forensic should be perceived as a nonlegal investigative procedure.

Construction projects are extremely dynamic and complex and consist of multiple interdependent "components," which have multiple interacting feedback processes, and numerous nonlinear relationships [69]. In addition, they are essentially "human" enterprises, and cannot therefore, be fully understood (or conveniently represented) solely in terms of technical relationships among these components. Most of those data needed to understand the evolution and dynamics of design management problems (that are experienced in projects) are primarily concerned with managerial decision-making and other so-called "soft" variables. This characteristic in itself contributes to the complex nature of the problem at hand [54]. As an analysis tool, system dynamics has been used to model a wide range of construction and engineering issues, for example:

1) client and project management relationships [36];

2) civil engineering contracting work [67];

3) delays and disruption [3], [27];

4) the design process of engineering [54];

5) the impact of change orders and rework [40], [43];

6) the effects of initial scope on project performance [20];

7) dynamic planning for fast tracking projects [57]; and

8) the cost and time performance of design and build projects [21].

Only limited research has examined the behavior and underlying causes of design-error-induced rework in construction and engineering projects [4], [46]. In fact, the underlying managerial and organizational process that causes errors has not been systematically examined [62]. By using system dynamics, the behavioral characteristics associated with the production of rework and its impact on project performance can be assessed.

\section{B. Management and Organization: Design Errors}

Errors are unintended deviations from correct and acceptable practice, and thus, are avoidable [37]. While errors are deemed to be avoidable, it is a matter of contention whether individuals can justifiably be blamed for all errors, as making mistakes is an innate characteristic of human nature [38], [61].

1) Skill Base and Experience: There are three types of human errors [37]; errors due to poor knowledge, errors due to carelessness and negligence, and errors of intent (i.e., due to greed). Poor knowledge is often a result of insufficient education and training, and experience. Carelessness and negligence include errors in calculations and detailing, and incorrect reading of drawings and specifications. These are errors of execution and are a result of lack of due diligence. Regardless of the skill level, experience, or training that individuals possess, errors may be made at any time during a project's life cycle [6], [31], [47], [55], [73].

Fig. 1 presents an influence diagram that identifies key issues from the literature in the design phase (i.e., conceptual, schematic, and detailed design) that can influence a designer's cognitive reasoning, and therefore, their likelihood to commit errors [8], [61]. Other factors, such as ineffective use of computer-aided design [25], low task awareness, overload, fatigue and stress, lack of teamwork, lack of awareness of changes in standards, and not knowing what is required are also factors that can contribute to designers making errors [4]. During the construction phase of a project, effort and time is expended in 


\section{Design}

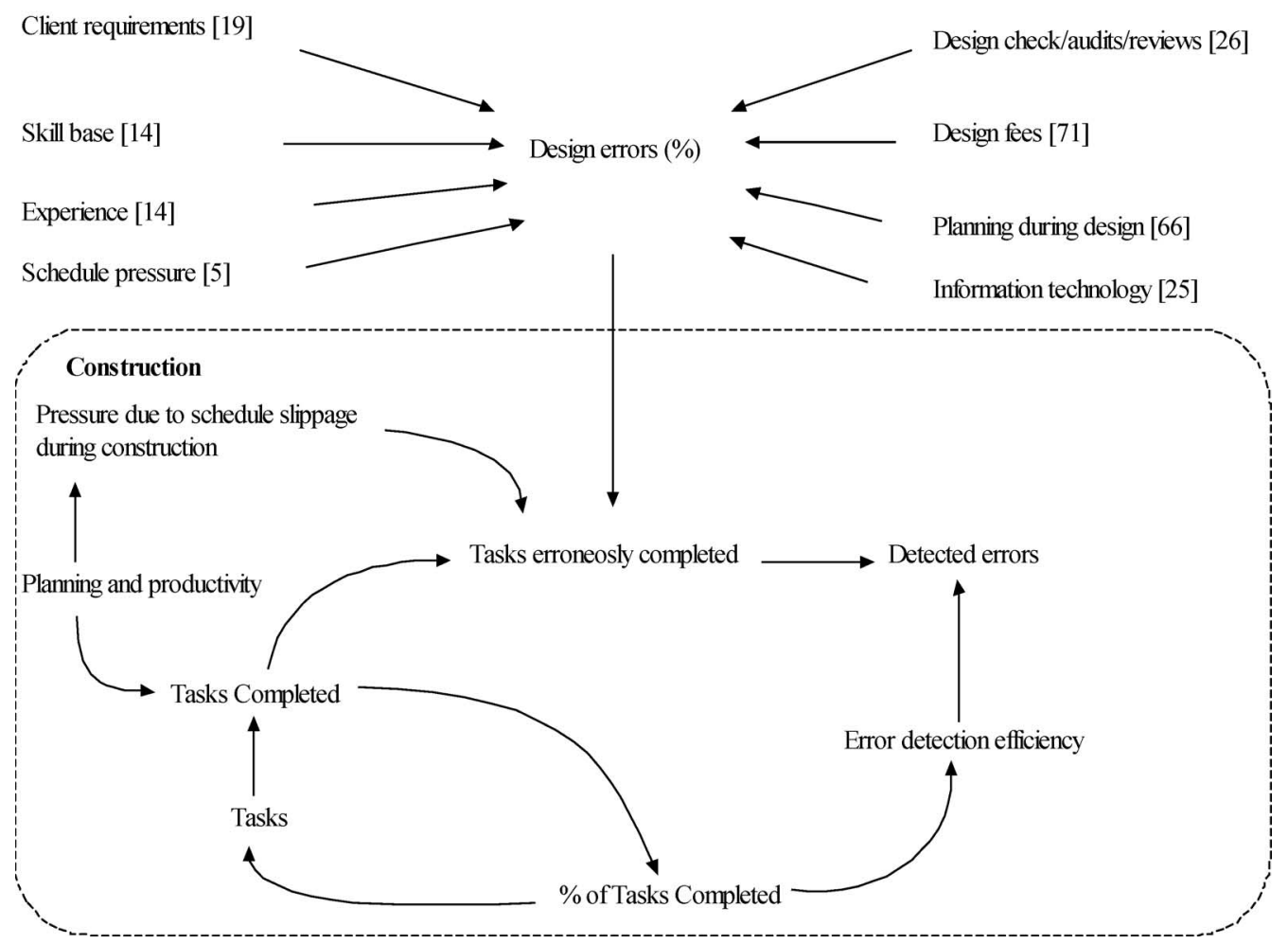

Fig. 1. Influence diagram of design-error-induced rework.

attempting to identify and correct the specific design errors that have occurred. When there is pressure to complete a project or activities, then some tasks will be completed erroneously and there will invariably be a time delay before they are identified. The processes that generated the error(s) may also continue to create additional problems that appear later, and therefore, may have a significant effect on project schedule as well as the morale and motivation of the project team.

2) Client and End-User Requirements: Generally, designchange-induced rework is client-initiated and invariably results in a modification to the contract, where the resultant impact on cost and time are mutually agreed upon by the client and contractor [78]. Another aspect is not understanding the client's requirements, and subsequently, commencing the process of design without communicating to the client their intentions or interpretation of what they or end-users require. Noteworthy, different client types with varying experiences can influence the effectiveness of the communication process with their designers, especially when buildings are commissioned by clients who are not themselves the users of the facility. Frequently, communication between designers and the end-user of the facility is indirect, and as such, tends to be filtered by organizational politics [39]. In some cases, a client's representative may attempt to act as a communication channel between the design team and end-users in order to drive through issues or maintain a powerful position in the system. While this may provide the client with increased control over the design team, it can also serve to make their task of understanding the problem more difficult.
Even if such barriers do not exist between the client and design team, communication gaps still tend to exist between the design team and client with end-users [41], [88]. Love and Li [42], for example, found changes during construction initiated by endusers can account for up to $25 \%$ of rework costs that occur in a project. There can be instances, however, where design team members are the source of an error and a design change is later required when the error is detected during construction [41]. Previous examples have shown design errors to have accounted for 30\% [1] and 38\% [74] of rework in a water treatment and industrial engineering project, respectively.

3) Schedule Pressure, Design Fees, and Planning During Design: Design is a complex, challenging, and creative process that is often driven by personal motivation coupled with the desire to satisfy client needs [39]. Moreover, it is a specialized and highly demanding form of problem solving [57], [60]. The "personal" need to satisfy creative desire is restrained within the confines of what is possible in the architectural and engineering process [30]; and of course, by economic constraint. Set against the general aim of achieving a functional design solution, innovation, and high quality is the continuos pressure to meet the immediate needs of clients; these principally being cost and time parameters.

An unrealistic client demand for earlier completion of projects has been found to be a factor that contributes to the production of incomplete and erroneous contractdocumentation [71], [72]. Lack of attention to management and providing a poor quality service by design consultants has resulted in rework becoming 
a norm and profits being eroded within architectural firms [41]. Contract documentation quality may be compromised when a firm submits a low design fee for a project, especially when design tasks are subject to "time boxing." That is, a fixed period of time may be allocated to complete each task, irrespective of whether the documentation or each individual task is complete or not. Poor workload planning within design organizations can also contribute to "time boxing" and result in inadequate time to prepare complete design documents. The use of inexperienced staff that possess limited technical knowledge may lead to errors and omissions in contract documentation being made. Findings resulting from a study on the technical design of buildings found that the most frequent causes of severe deviations during design were attributable to deficient planning and/or resource allocation, and deficient or missing input and changes [72].

4) Design Checks, Audits, and Reviews: Prior behavior can have an impact on the choices that an individual makes. Once an individual has learned that a particular behavior provides a viable solution to a decision problem, the learned behavior is likely to be repeated when a similar situation arises [35]. When subjected to time pressures, individuals will tend to maintain their routine when reencountering the same choice problem, even after having formed the intention to choose an alternative behavior. In some circumstances, individuals may decide to deviate from their routine behavior [9]. For instance, if routine behavior repeatedly produces negative outcomes, the individual may decide to purse an alternative course of action in their future problem solving [10]. Though, an individual's knowledge is typically limited to their own activities, which can contribute to their inability to detect errors [47].

Once construction has commenced, the financial and time implications of rectifying errors can be considerable once they have been identified. Invariably, there will be a number of tasks completed during design erroneously. This is because design firms tend to negate implementing rigid quality management practices, such as checking and auditing [45], [66], [72]. While the effectiveness of checking and inspecting design details and specification has been advocated as a mechanism to detect errors [70], the process of checking itself tends to be intermittent, and as a result, all errors cannot be expected to be identified [37]. Furthermore, individuals checking a design for errors invariably make the same mistakes as the original perpetrators [59]. The process of checking may become more arduous when design activities, such as architectural, mechanical, and structural engineering, are subjected to concurrency (degree of overlap between activities), otherwise known as parallelism [76]. In other words, as tasks are performed concurrently, the number of interactions increases and the likelihood for errors to occur also increases. Noteworthy, there is a limit to the number of tasks that can be undertaken in a concurrent manner [33]. Beyond this specified limit, the probability of rework occurring as well as time and cost overruns being experienced significantly increases. This is exacerbated when the design team is under pressure due to schedule slippages as a result of occurrence of errors or change orders being undertaken. As a result of this pressure on design team members, more errors may be made. According to Cooper [17], construction projects can take as much as two and half cycles to rectify rework activities in construction projects. Acknowledging that there will be design errors committed, it is then the role of the Project Manager to ensure that error detection mechanisms are in place. A more detailed review of rework causes in construction projects can be found in Love et al. [46].

\section{RESEARCH APPROACH}

To determine the causal variables of design-induced rework, the traditional scientific concept of causality founded on the monocausal model in the physical and biological sciences is subject to subtle changes, and adapted to a social context as construction projects are essentially complex social systems [51]. In this instance, causality is not considered to be linear, proportional, or incremental, but multidimensional, whereby each factor is interrelated and multicausal in nature. Furthermore, rational assumptions underlying the decision-making process are not a presiding factor in explaining the nature and performance of projects [48]. The assumption that decisions cause action and that decisions occur before actions has been the subject of debate and is questionable [15], [22]. That is, decisions can be made after actions, and therefore, in some ways, made to legitimize them [48].

An alternative to the bounded rationality of the decisionmaking perspective is the action-orientated approach [23], which views organizational performance as a chain of disparate actions that need to be understood if developments in an organizational setting are to be explained [48]. The need to perform specific actions to achieve immediate goals is the underlying rationale for the existence of a project [56]. When errors are identified, goals may be prone to subtle shifts, which may disrupt the transitioning of tasks and impact the project's performance. Errors by their very nature are actionable events, and so propagating knowledge about why and how they occur can used to contribute to the contextual development of project management theory.

The boundaries for the case study were defined as corresponding to the construction period on-site. This was because of the immediate availability of the project to the researchers. The boundaries of the project were also taken to include only those individuals, who were most directly involved in the project. In essence, these individuals act as primary informants for rework determinants. In many cases, the focal project team is readily identifiable inasmuch as they are required to be involved throughout the postcontract phase of a project, especially under a traditional lump contract.

Errors that had been made during the design phase remained in a state of incubation until their identification (most usually as "problems") during construction. Once identified, an investigation as to how and why these errors occurred was undertaken. The case study project was selected because of its availability and because the participating organizations were willing to participate at the time the research was to commence.

\section{A. Data Collection}

The researchers acted as nonparticipant observers throughout the duration of the data collection process on-site. Data was 
TABLE I

COST INCREASES INCURRED IN THE PROJECT

\begin{tabular}{|l|c|}
\hline \multicolumn{1}{|c|}{ Cost summary } & \% of contract value \\
\hline Direct cost overrun & $10.50 \%$ \\
\hline Change orders initiated by client and occupiers & $7.35 \%$ \\
\hline Total direct rework costs & $3.15 \%$ \\
\hline (a) Rework due to design changes and errors & $2.7 \%$ \\
\hline (b) Rework (minor defects) & $0.45 \%$ \\
\hline
\end{tabular}

collected from the date on which construction commenced onsite to the date of practical completion. The site was visited between one and three times a week throughout the duration of the project and each visit lasted between 2 and $5 \mathrm{~h}$. The time allocated for collating rework data varied because during the early stages of the project there were very few incidents reported or identified by the contractor's project manager. Two block visits of 4 days were also conducted to coincide with a period of increased site activity. The researchers acted as observers, and at times, relied on their industry experience to identify rework events that occurred while reading through the contract documentation (i.e., site instructions, change order requests, requests for information, drawing changes, etc.), which was stored in the main site offices. However, before any event was categorized as rework, its validation was sought from the contractor's project manager, site foreman, and contract's administrator. Every attempt was made not to disrupt the workflow of the site management team and subcontractors.

The research relied on reports of individuals' historical events that are open to biases to do with recall and self-presentation. Independent verification of the inferences made from interviewees was made. Multiple sources were used to triangulate these data so as to obtain a balanced view of the problem at hand [64]. Triangulation was used to cross check for internal consistency and reliability, and to test the degree of external validity of the data. Documentation provided by the contractor and unstructured interviews with project team members (e.g., architect, structural/mechanical/electrical engineers, site management team, and subcontractors) were the primary sources of information for determining the causes and the costs of rework that were experienced. A total of 130 interviews with the client's representative/project manager, design consultants, the contractor, subcontractors, and end-users, which ranged from 20 to $90 \mathrm{~min}$ in duration, were undertaken during the project's construction phase. Once a rework event was identified, then all parties involved with identification and rectification were interviewed so a balanced view of the event could be established (Appendix B). Data derived from the interviews were transcribed and then given to the interviewee to check for any discrepancies that may have arisen. Data was then analyzed using content analysis software QSR N5 and coded according to the rework classification system presented in Love and $\mathrm{Li}$ [42].

\section{B. Case Study Background}

The project consisted of two residential blocks of six-storeys each, which combined comprised 43 units. An underground car parking, a landscaped podium, and a swimming pool were among the facilities incorporated into this development. The project had a contract value of A $\$ 10.96$ million, a contract period of 43 weeks, and was procured under a traditional lump arrangement. A 5-week extension time was granted. The project was issued with a certificate of practical completion 8 weeks ahead of the rescheduled completion date. While the project was delivered ahead of time, cost overruns were experienced due to change orders and rework (Table I).

There was a direct cost overrun of an additional 10.5\% (A \$1 $105900)$ of the original contract value. Change orders as result of additions initiated by the client and occupiers accounted for $7.35 \%$ (A\$806 356) and 3.15\% (A \$345 504) were a direct result of rework. Design changes and errors that resulted in rework accounted for $2.7 \%$ (A \$299 544) of the original contract value. The remaining $0.45 \%$ ( $\$ \$ 45960$ ) of rework costs were due to minor defects.

Despite the cost overrun, the client and contractor's project manager considered the project a success, and mainly attributed this to a dedicated and proactive site management team and well-managed interorganizational relations with subcontractors. In particular, the contractor's site management team had worked together on previous projects, which contributed to their overall effectiveness and efficiency. Essentially, the team established a flexible network of relationships, which was used to accomplish tasks. The project manager had over 30 years of experience in the local industry, with several years as an experienced carpenter and foreman prior to joining the contracting firm. Many of the subcontractors had previously worked with the project manager, and thus, had developed good working relationships.

The design consultants, with the exception of the quantity surveyor who was ambivalent about the project's success or failure, considered the project to be a success for the client and occupier, but not from their organization's point of view: they simply did not make any profit because resources had to be used to rectify design errors that had been made in the contract documentation.

\section{Causal Behavior of Design-Induced Rework}

While the rework cost experienced in this case study is considerably lower than those reported in other studies [13], [28], [43], [53], [74], the design consultants and subcontractors (e.g., structural steel and ceiling and partitions) expressed a great deal of dissatisfaction with its occurrence. Extensive changes were required to their original scope of work due to design errors that were contained in the contract documentation. Even though the project was delivered ahead of schedule, the fact remained that a significant cost overrun was experienced, of which $42 \%$ was attributable to rework. This is comparable with the research undertaken by Love [43] who found, on average, that rework 


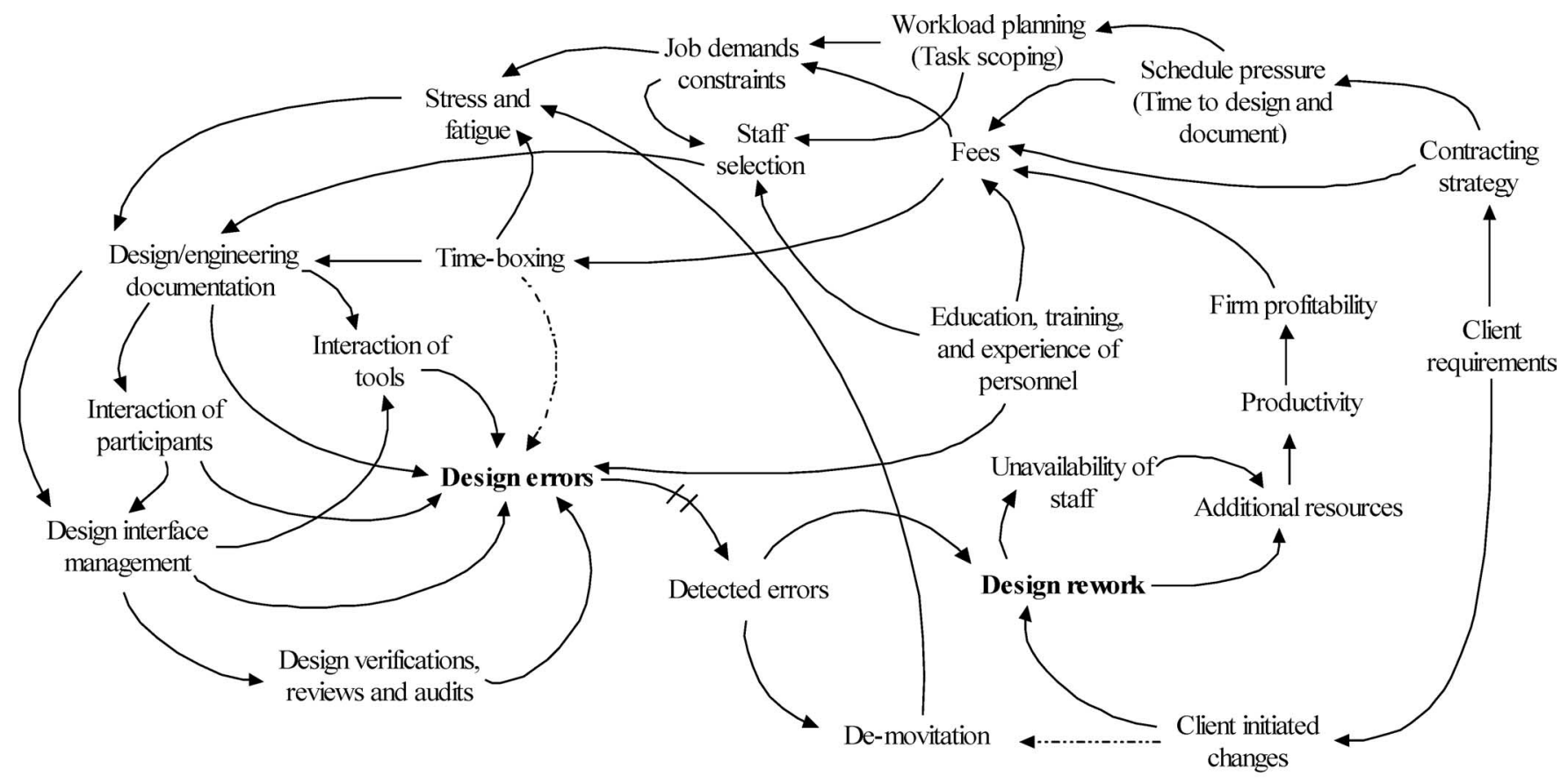

$\backslash$ Denotes a delay (i.e. a time delay before the error is detected)

Fig. 2. Causal loop diagram of design-error-induced rework.

contributed $52 \%$ of a project's total cost overrun. No single cause for a design error could be identified from the analysis, and in many instances, the events that did occur were interconnected with one another. Building on the influence diagram presented in Fig. 1 and antecedents that will be presented next, a systemic model of the interrelationships between the key factors that were found to influence design-induced rework from the case study findings was developed (see Fig. 2).

1) Client Requirements: Understanding client requirements is pivotal to project success. The communication of these requirements to the design team during the concept and detailed design stages was the responsibility of the client's project manager. Such communication occurred in a piecemeal fashion and limited attention was given to the design management interface (e.g., design coordination meetings). This less than optimal situation was further exacerbated by the late appointment of the design engineers (structural, mechanical, electrical, and hydraulics), which meant that the architect had designed and began documenting the project before the engineers could offer their specialist input. Resultantly, the service engineering consultants had to compromise their design of the project's services (i.e., to accommodate the completed architectural design). A specific example is that the architect specified the floor to soffit height of the basement slab to be $2.1 \mathrm{~m}$. While this clearance did correspond with the minimum requirements of the building code, no allowance had been made for the inclusion of basement hydraulics (storm water and sewer drainage).

2) Design Interface Management: The client's project manager had limited experience and knowledge of residential developments, because they had only been involved with project man- agement of small industrial projects. Additionally, the client's project manager neglected to acknowledge that when a task is process dependent, effective coordination of information flow between subunits is critical. This lack of design coordination, particularly between the architect and structural engineer during the design process, meant that both consultants lost sight of their respective roles in the project, and instead, concentrated on their own objectives and goals. The architectural and structural and drawings did not correspond with one another and contained an excess amount of errors, which were only detected on-site by the contractor. The noninteraction between key project participants resulted in the contractor's project manager making the following comment:

\footnotetext{
You wouldn't believe that they were working on the same project. The architectural drawings were incomplete, and the pitch of the roof was too steep, which meant that the building exceeded the height stipulated by Brisbane City Council.
}

Problems that were identified by the contractor were passed on to the client's project manager, who then informed the architect and structural engineer of the issues to be addressed. The relatively fixed "power structure" established by the contract meant the contractor was suppressed from directly contacting the architect and structural engineer, for example, to request further information. Any requests for information (RFIs) that were raised by the contractor and their subcontractors about design errors had to be sent directly to the client's project manager, who then distributed the RFIs to the respective party. This caused a bottleneck in the flow of information and contributed to less attention being given to coordination by the 
client's project manager. Even more surprising was that the RFIs were not immediately forwarded to the architect and engineer, which resulted in periods of inactivity being experienced by the contractor.

The architect and engineering consultants did not have compatible software tools, which contributed to coordination issues and made checking, when it did occur, a nebulous task. Clearly, the use of a convenient and common platform for information exchange and storage could have significantly reduced their time to update and modify contract drawings.

3) Schedule Pressure and Fees: The architect and engineering consultants were quality assured to ISO 9000; however, limited checks in the form of design verification and reviews were undertaken prior to documentation leaving their respective offices. Both the architect and engineers stated that the design program they had been given by the client's project manager was unrealistic. In fact, adequate resources were unavailable to sufficiently complete the detailed design as their original fee was based on the concept brief and only a certain number of hours per week were to be allocated to the project. The design consultants did not realize the full extent of the work to be undertaken at the time they tendered their services for the project. This resulted mainly because the brief given to them was evolving simultaneously with the design.

Although most design consultants will deny their use of "time boxing," it was revealed, albeit in informal discussions, that this practice was resorted to by the design firms. The practice of time boxing is used to allocate a fixed time to complete the contract documentation, as a means of controlling resource expenditure. Such actions almost always result in errors, especially when there is schedule pressure from the client. While those designers interviewed acknowledged that this practice was unprofessional, they "hoped" that their designs would be adequate and that any errors identified by the contractor would be straightforward to address. Furthermore, graduates rather than more senior architects were used for contract documentation, as a further means of reducing design costs.

4) Fatigue and Stress: Due to schedule pressure and the necessity to maximize their fee, the design consultants were subjected to increasing job demands (i.e., working fast and hard, having a great deal to do, not having enough time, and having conflicting demands) as errors were identified. The fast work pace of the project imposed physical requirements on the project team, which invariably resulted in physical fatigue being experienced. For example, the anxiety associated with the need to maintain the pace of work and associated consequences of failing to complete work, contributed to the project architect becoming demotivated and experiencing a high degree of stress. As a result, the architect had to go on sick leave for a month, at a time when a number of critical design errors had to be rectified. During this period, additional staff were supplied to the project to address the errors and other queries that arose. Because these staff had limited knowledge of the project's internal dynamics, particularly the issues associated with the design and the status of its completeness, there was a degree of reluctance to fully immerse them into solving the incomplete work. There was simply no motivation to take on erroroneous work.

\section{Modeling Key Behavioral Dynamics}

The causal loop diagram presented in Fig. 2 was subjected to validation by six industry practitioners (two each of architects, structural, and mechanical engineers) using unstructured interviews. Each of these interviews was approximately $1 \mathrm{~h}$ in duration. The factors identified and their respective relationships were considered by these practitioners as representative of practice.

The case study findings revealed the underlying behavioral dynamics that contributed to design errors related to the management of the design documentation process. This was also confirmed by the practitioners during the evaluation process of the causal loop diagram. In addition, the process associated with the production of design documentation is also considered to be problematic in Australia [72], and therefore, this process was chosen to be modeled and simulated in this study.

Key aspects associated with the management of the design process are the: process of inducting and recruiting design personnel, process of design tasks, degree of error proneness (i.e., the capacity of design personnel to make errors), and redesigning previously completed tasks [2]. Each of these aspects is now discussed in more detail.

1) Inducting and Recruiting Design Personnel: Typically, the composition of personnel within a design firm will vary with the firm's size and workload. There are, however, three different classifications of designer: experienced; newly recruited; and inducted (i.e., an experienced designer working on other projects within the design firm but seconded to a new project). The productivity and accuracy of tasks undertaken during the design process will vary from one classification of designer to another [2], [14]. When determining staffing levels within a design office, one would reasonably assume that the partner(s)/office manager takes a rational approach to selecting and recruiting new staff. Therefore, based on their design schedule, the partner(s)/office manager will determine the number of designers needed for a project and then compare this requirement with those designers who are available. Any difference between the number of designers needed and those available is referred to as the shortfall (not enough) or surplus (more available than needed). If there is a shortfall, the partner/office manager may decide to either recruit additional staff or internally induct staff. In either case, the new designer(s) will have to become familiar with the project's characteristics, requirements, and history. Consequently, a delay (or reduction in productivity) is experienced before they become knowledgeable about the project, and thus, can be classified as an "experienced designer."

2) Process of Designing Tasks: Design tasks are assigned among the three different groups of designers (referred to earlier). There are two possible design outcomes from the design groups-the design is completed correctly or it is not. Depending on the error proneness of the designer (that is, the capacity of the designer to make mistakes), the number of correctly designed tasks can be approximated (although this approximation will always be prone to variance). For the purposes of modeling, the number of tasks designed correctly and incorrectly by each of the three classifications of designer will be identified (see the following paragraphs). 
3) Error Proneness During Design: The factors that contribute to error proneness are parallelism, schedule pressure, and design fee pressure. These contributing factors have been confirmed from the case study findings and the literature. The authors have assumed that the identified designer types will each be subject to different degrees of error proneness [2], [14]. Therefore, a nominal value for committing errors is assumed in the model, as shown in Table I. This error value is deemed to rise due to any combination of: schedule pressure increases, when design fees are low; and when the degree of parallelism between design tasks increases. Low salaries can act as demotivators, which, in turn, may also contribute to the incidence of errors. Similarly, when a firm submits a low design fee for a project, it may "time box" tasks, which can increase pressure on designers and encourage mistakes. Parallelism may bring with it mistakes as discussed earlier.

4) Redesigning Design Tasks: Once the design and contract documentation is complete, it is passed to the contractor to price. At this point, the authors assume the contract has been let to a selected main contractor and construction has commenced on-site. As construction progresses, errors are inevitably found in the contract documentation. Similarly, some elements of the building may be constructed incorrectly. If an error is proved to be the responsibility of the contractor (or a subcontractor), then it may be rectified (rework) with no added cost to the client.

On the other hand, if the architect or engineer caused the error, then they will be responsible for solving the problem. Unless it is a simple problem, a particular item or selection of work may need to be redesigned. The design firm may have to recall the designer(s) responsible for that part of the design and documentation process to undertake the necessary rework. If the original designer(s) have left the firm, the process of recruiting/inducting may well commence again. However, for the purpose of this paper, the authors have assumed that the designer(s) can be readily recalled to the project. It is assumed that as construction progresses on-site, errors in the contract documentation will be identified by the contractor/subcontractors. As they are identified, the process of confirmation and redesigning of tasks will commence.

\section{A. Simulation Modeling}

The mechanisms explained earlier have been expanded further to develop a simulation model for analyzing error in design. The flow diagram presented in Appendix A details the assumed parameters of the model with respect to the process of inducting/recruiting design staff. A detailed discussion about the formulation of the major equations used to develop the model is beyond the scope of this paper, but they can be viewed in Appendix B. Estimates for the model's parameters (i.e., project duration and contract value) were derived from the case study. In addition, the industry practitioners provided estimates for designer salaries, and design fees, which ranged from 5 to $10 \%$ of project costs. In conjunction with industry practitioners, the authors have determined the parameters used to model the influence of design errors. Table II identifies the data and assumptions made in the model for generating a series of possible scenarios
TABLE II

DATA AND MODEL ASSUMPTIONS

\begin{tabular}{|c|c|}
\hline Characteristics & Assumption \\
\hline Designer's average salary & $\$ 1000$ per week. \\
\hline Scheduled design completion time & 40 weeks \\
\hline Project cost & $\$ 10960000$ \\
\hline Design fees (in percentage of project cost) & $5 \%$ \\
\hline Estimated effort in the design stage & 548 person-weeks \\
\hline Construction start time & $40^{\text {th }}$ week. \\
\hline Available designers (initially) & 10 persons. \\
\hline Construction period & 43 weeks \\
\hline \multicolumn{2}{|l|}{ Design error proneness } \\
\hline - by expert designers & $10 \%$ of tasks \\
\hline - by designers inducted from other projects & $20 \%$ of tasks \\
\hline - by newly recruited designers & $25 \%$ of tasks \\
\hline
\end{tabular}

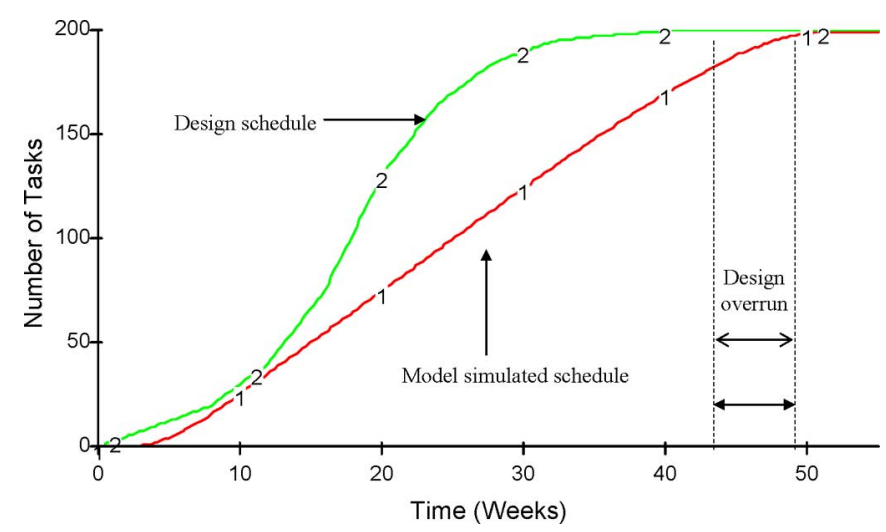

Fig. 3. Simulated completion of design tasks versus the actual schedule.

for a given project based on the findings derived from the case study.

The process of model validation is multifaceted. The model has been examined for structural validation inasmuch as the major factors identified from the case study and literature have been used and the values used in the model validated by industry practitioners. The model is tested for behavior prediction so as to assist practitioners with particular scenarios they may be faced with. Fig. 3 depicts the model's simulated behavior for the time allocated for the design and documentation process, in comparison to the actual design schedule.

For the example used in this paper, the model shows a simulated design completion time of 45 weeks (for the completion of $95 \%$ activities) compared to a scheduled design completion time of 40 weeks (Table I). Fig. 3 shows the behavior of actual design activities completion against the forecasted schedule. The actual progress always remained below the scheduled design activities. This is explained by the fact that the design firm takes time to recruit and train design personnel. However, design firms often neglect this factor when planning their design schedule for projects [54]. Fig. 4 exhibits the allocation of design staff during the documentation process, which identifies that more design staff are allocated during the early stages of 


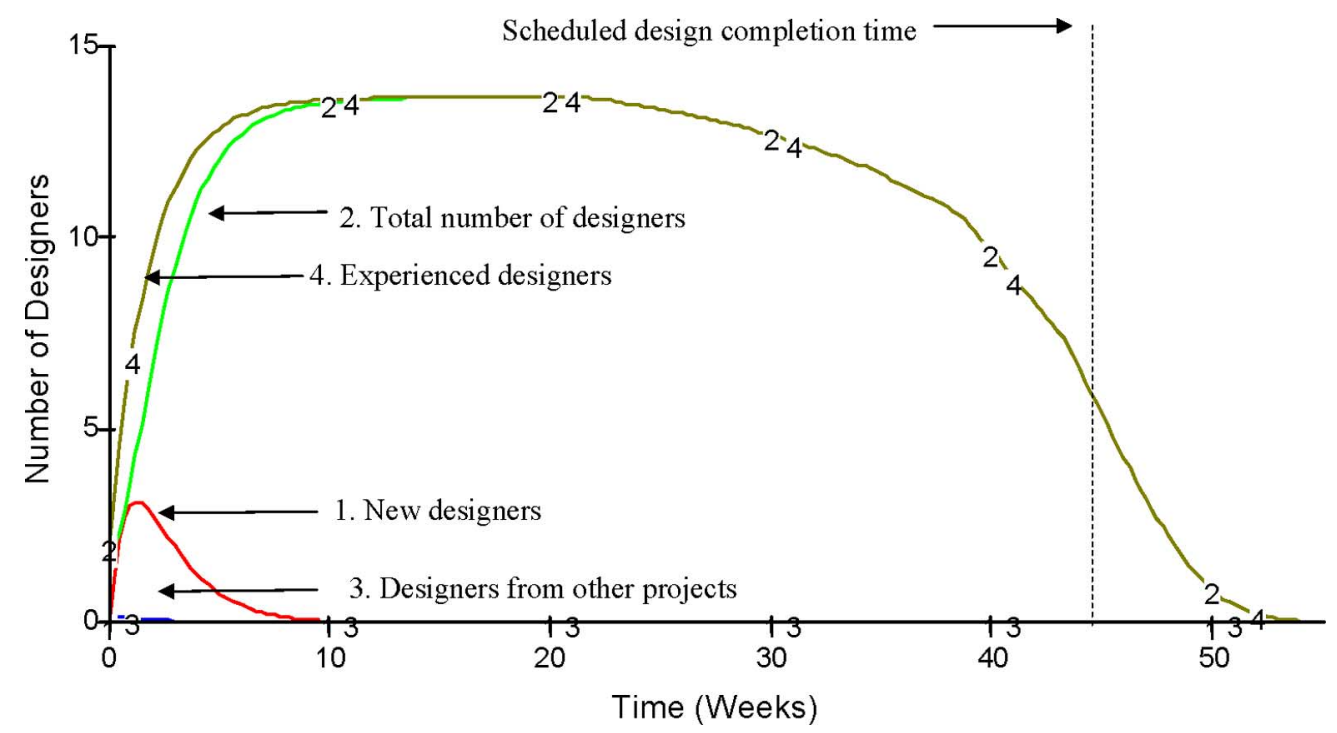

Fig. 4. Number of design staff required during the documentation process.

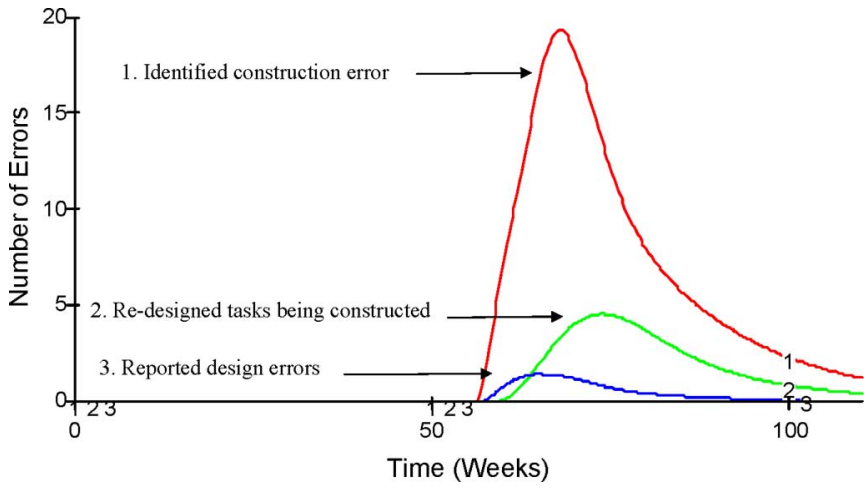

Fig. 5. Occurrence of errors during on-site operations.

the project. Similarly, the number of design staff decreases as tasks are completed.

The actual effort (measured in person-weeks) in the documentation process is marginally above the estimated effort, that is, 556 person-weeks against the target of 548 person-weeks. At least 43 activities in total have been modeled and are designed erroneously in this example. It is assumed that of these, 28 errors are design-based, which are detected on-site, and therefore, have to be redesigned. Fig. 5 shows the time-dependent behavior of identified errors and their rectification.

The period for amending errors (redesigning of activities) takes 14 person-weeks effort (refer to Table II). With a 40-week period for documentation and 43-week construction period, the simulation indicates that at the 105 th week only $95 \%$ of activities will be completed. "Time boxing" may occur at, or even before this point is reached. The number of designers that need to be recalled during construction for correcting errors was simulated and calculated. Though, in practice, only a fraction of a single designer's time is utilized in correcting errors, over the whole project the total redesign time was equivalent to one designer working full time on correcting errors for 14 weeks.

\section{B. Testing of Alternative Scenarios}

To further understand the dynamics of design-error-induced rework in a project system, the following scenarios were tested:

1) Scenario 1: Continue with the present situation.

2) Scenario 2: Reduce design time-Due to external pressure, a project manager could accelerate the design and documentation process of the project. For example, the design schedule could be compressed from 40 weeks to 25 weeks. No other change is effected: Salary is $\$ 1000$ per person per week; available design personnel from other projects are ten.

3) Scenario 3: Reduce design time with engagement of experienced design personnel-It is assumed that paying an additional salary (in terms of overtime payments) will be attractive to experienced design staff. The salary is increased by $50 \%$ to $\mathrm{A} \$ 1500$ per person per week. The scheduled design completion time is kept at 6 weeks.

4) Scenario 4: Recruit a high proportion of design personnel from external sources - In the event of being awarded a new contract, design firms in normal circumstances use their existing personnel, as this may be less disruptive. However, if there is a shortage of internal design staff, the design firm may have to externally recruit design staff. Reducing the number of available design staff from ten to five can test this scenario. Salary is set at $\mathrm{A} \$ 1000$ per person per week and the scheduled design completion time is 6 weeks.

5) Scenario 5: A combined policy incorporating a design fee reduction, short design delivery period, and reliance on external supply of design personnel-Design fee is reduced from $5 \%$ to $4 \%$ of project cost. Design completion period is 25 weeks and the available design personnel from internal sources are only 5 .

In Scenario 2, the design schedule is reduced from 40 weeks to 25 weeks. Consequently, this requires designers to raise their productivity without an increase in salary, which may have a 
TABLE III

SUMMARY OF SCENARIOS TESTED

\begin{tabular}{lcccccc}
\hline Scenario & $\begin{array}{c}\text { Effort in } \\
\text { design } \\
\text { (person- } \\
\text { week) }\end{array}$ & $\begin{array}{c}\text { Number of } \\
\text { tasks } \\
\text { designed } \\
\text { erroneously }\end{array}$ & $\begin{array}{c}\text { 95\% Design } \\
\text { completion } \\
\text { (weeks) }\end{array}$ & $\begin{array}{c}\text { 95\% } \\
\text { Project } \\
\text { completion } \\
\text { (weeks) }\end{array}$ & $\begin{array}{c}\text { Number of } \\
\text { activities } \\
\text { redesigned }\end{array}$ & $\begin{array}{c}\text { Effort spent on } \\
\text { re-design } \\
\text { (person-weeks) }\end{array}$ \\
\hline Scenario 1 & 556 & 43 & 45 & 105 & 28 & 14 \\
Scenario 2 & 585 & 82 & 30 & 98 & 53 & 26 \\
Scenario 3 & 390 & 48 & 29 & 98 & 35 & 27 \\
Scenario 4 & 585 & 84 & 30 & 98 & 54 & 21 \\
Scenario 5 & 468 & 59 & 30 & 98 & 41 & 27 \\
\hline
\end{tabular}

demotivating consequence contributing to more errors being made. In this scenario, the effort to design has risen by $5 \%$ and the number of erroneously designed activities increased by almost $100 \%$. To complete the design activities in a shorter period, the design firm may have to recruit a large number of inexperienced personnel, but due to their high error proneness, errors may increase. As a result, the number of redesigned activities and the effort required would increase by $90 \%$ and $85 \%$, respectively, when compared to Scenario 1.

Scenario 3 appears to be a reasonable approach as a reduction in the design and documentation period would require the design firm to pay higher salaries for better qualified personnel. The implications of implementing this scenario are that the design and documentation period would be completed within 390 person-weeks and the required effort would be $30 \%$ less than that in Scenario 1. The number of errors in both the initial design and redesign stages is similar to that found in Scenario 1 (Table III).

The behavior observed in Scenario 4 is very similar to that in Scenario 2. In Scenario 4, due to the lack of available inhouse design staff, the design firm could be compelled to recruit inexperienced design staff from external sources. In effect, this may increase the number of errors, and consequently, more effort may be required during the design and documentation process. Moreover, as errors occur, increased effort may be needed to redo erroneous activities.

Scenario 5 may be considered to be the most inappropriate policy. A reduction in the design fee from $5 \%$ to $4 \%$ as well as a reduced design and documentation period may force the design firm to produce contract documentation with minimum enthusiasm and "time boxing," which can lead to higher levels of error being experienced.

The incidence of errors contained within contract documentation produced by architectural and engineering consultants, is considered to be alarmingly high in the Australian construction industry [72]. While it has been implied that the use of competitive tendering for professional services may have possibly contributed to this incidence, the fact remains that design firms need to adapt to the market conditions within which they operate. In the United States, for example, the Brooks Act was established as Federal law and implied that architects and engineers be selected on the basis of their professional qualifications, subject to negotiation of fair and reasonable compensation for such services [19]. Significant cost savings have been achieved for clients who have adopted the Brooks Act as a basis for procuring architectural and engineering services. Yet, the immediate challenge for the Australian construction industry is to shift from a "price-dominant" market to one that focuses upon quality-based selection. This will not only require a change in attitude and behavior from clients, but will also require the architectural and engineering consulting firms to rethink their work practices, and their approach to service delivery by putting the customer first. Simply asking for higher fees for services may reduce the incidence of errors in the short-term, but complacency can soon set in and a return to "old" work practices can be readily triggered by sudden shifts in market conditions.

There is always a danger that design-error-induced rework will creep up and settle in at an insidiously comfortable level, which may be accepted as an industry norm. If design consultants repeatedly produce design-error-induced rework, they may become invisible or come to be regarded, with complacency, at the cost of doing business. What is, in fact, a chronic malaise becomes "normal." Whatever the percentage increase that is taken up by rework, that percentage will be added to the firm's costs. So, if rework accounts for $10 \%$ of regular work of a design firm (or any other type), this would lead to everything being increased by $10 \%$ : supervision, cycle time for administrative procedures, answering requests for information, and so on. The time element obviously translates into costs, which are then buried in what would be considered "normal" operating costs.

History suggests that those who fail to learn from their mistakes are invariably condemned to relive them again. Insight gained from previous mistakes or oversights made in projects can be gainfully employed in preventing their repetition in the future. Learning from mistakes is a hard way to learn, but continuing to make the same mistakes is far harder and certainly more costly. In a competitive environment such as construction, embedded inefficiencies such as these may be the ultimate failure producing mechanism: in certain situations, mistakes can be disastrous. 


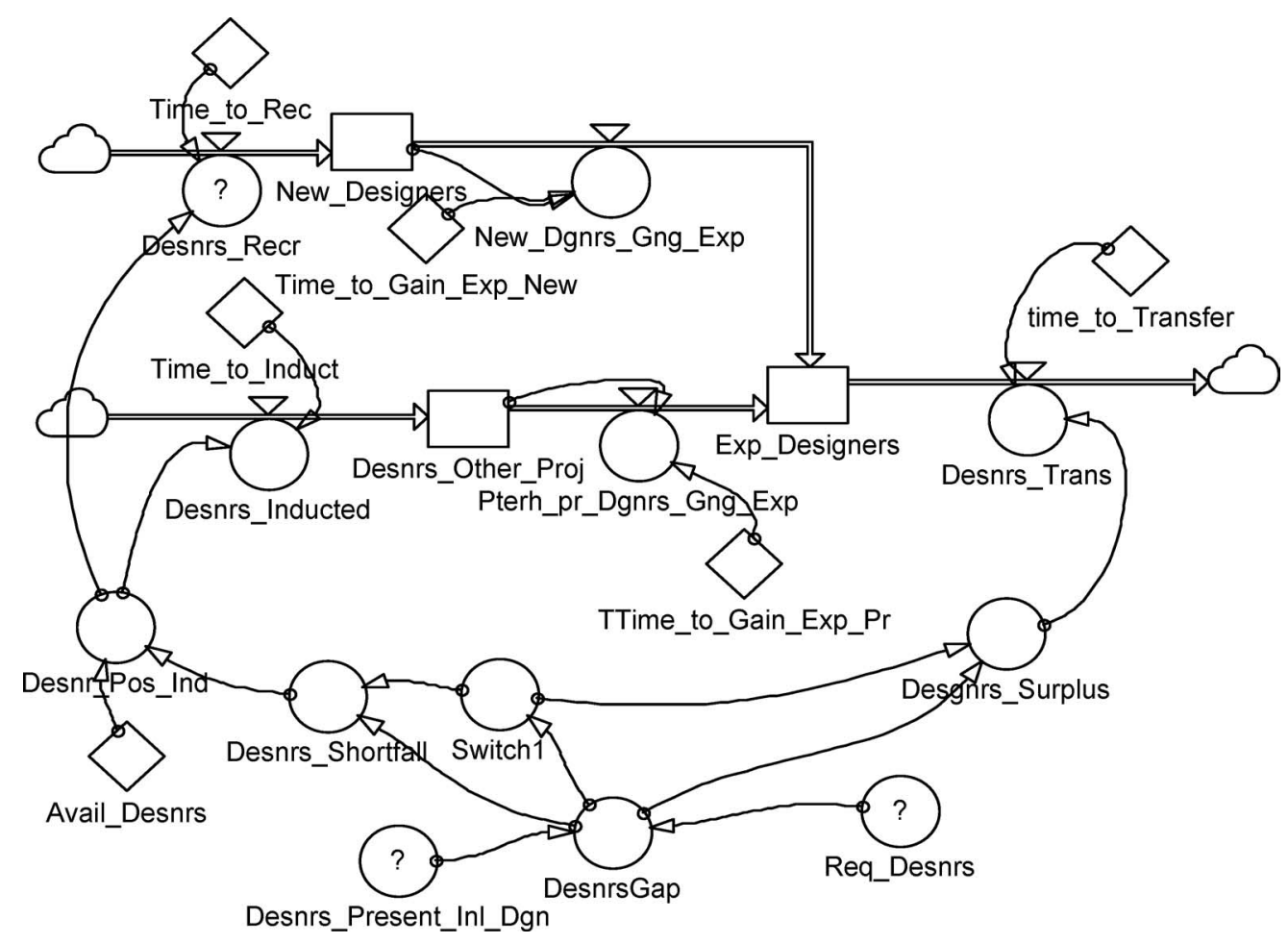

Fig. 6. Flow diagram for the process of inducting/recruiting design staff.

\section{Conclusion}

The construction industry in countries such as Australia, Hong Kong, Finland, Norway, Singapore, Sweden, and the United Kingdom have, and to a certain extent are going through a period of introspection, as they aim to improve the performance of the industry. It is widely acknowledged that time and cost overruns of projects plague the industry and strategies for improving project performance have been propagated. However, it has come to light in recent times that a major factor that has contributed to the incidence of cost and time overruns is rework, which typically manifests itself in the form of changes and errors. In this paper, the issue of design errors was examined and it was revealed that an array of factors contribute to their incidence in construction projects. The pressures imposed upon design firms from their clients to produce detailed design documentation can lead to errors being made, and as a result many of which may not be identified until construction commences on-site. The rework cycle that commences on identification of the error adversely impacts the performance of the design firm and the project. Some firms undertake design audits, design verifications, and reviews before documentation is distributed for tender, but this practice is not the norm, and there is ample evidence that suggests the contrary.

Undertaking design reviews and verifications is the first step to minimizing the potential impact of errors, but these practices will not prevent them from occurring. With this in mind, consideration needs to be given to planning the design process and making sure that resources are available to undertake the required work. Selection of appropriate firms must be on the actual skill level and experience of those staff that are actually going to manage the project's design process. In our previous paper [46], a holistic procurement model to reduce the incidence of rework in construction projects was propagated. In particular, the proposed model encourages firms to embrace interorganizational collaboration and learning, and as such, requires them to reexamine their work practices and methods in order to reduce rework. If firms do not begin to reexamine their work practices, then there is a danger that errors become a norm and adversely impact on their overall profitability and the performance of the projects that they are involved with. If design firms are to be competitive in today's environment, they should pay increasing attention to effectively managing their human resources and implementing quality management practices.

\section{APPENDIX A}

The flow diagram (Fig. 6) identifies the major levels and rate variables associated with inducting and recruiting new and experienced designers.

The actual number of required designers (Req_Desnrs) is calculated based on an estimated number of designers (Est_Reqd_Dgnrs) and a multiplier (Reqd_Dgnr_Mult), as shown in (1). This multiplier is dependent on the percentage of tasks that are to be designed, which is also dependent on the size and complexity of the project, as shown in (2)

$$
\begin{aligned}
& \text { Req_Desnrs }=\text { Est_Reqd_Dgnrs } \times \text { Reqd_Dgnr_Mult } \\
& \text { Reqd_Dgnr_Mult }=f(\text { Perc_Tasks_to_be_Designed }) .
\end{aligned}
$$

The estimated number of designers depends on two factors: the time available to complete the design tasks and estimated 
effort (in terms of design hours). Thus, if the scheduled time for completing the design process were considered to be short, then the estimated number of designers needed to complete the firm's requirements would be increased proportionally (3)

$$
\begin{aligned}
& \text { Est_Reqd_Dgnrs } \\
& \quad=\text { Estimated_Effort / Sched_Dgn_Comp_Time }
\end{aligned}
$$

Estimated_Effort $=$ Design_Fee / Dgnr_Salary.

Equation (4) assumes that the firm's design fee (Design_Fee) and the average salary of designers (Dgnr_Salary) determine the estimated effort (Estimated_Effort) needed to conduct a series of design tasks. The model is used to calculate the gap between the required and actual number of designers employed at every simulation interval. The model uses this information to determine whether or not designers need to be hired/inducted from other projects (5)

$$
\begin{aligned}
& \text { DesnrsGap }=\text { Req_Desnrs }- \text { Desnrs_Present_Inl_Dgn } \\
& \text { Desnrs_Present_Inl_Dgn }=\text { New_Designers } \\
& \quad+\text { Desnrs_Other_Proj }+ \text { Exp_Designers. }
\end{aligned}
$$

Equation (6) assumes the actual number of designers (Desnrs_Present_Inl_Dgn) equals the number of newly recruited designers (New_Designers) plus the designers transferred from other projects (Desnrs_Other_Proj) plus the experienced designers (Exp_Designers). If the actual number of designers were less than required, then there would be a need for additional staff through recruitment or induction of existing designers to the project. As mentioned earlier, designers are available from two sources: external recruitment, and the induction of existing designers from other projects currently being undertaken by the design firm. The number of new designers decreases as they gain experience through the training/familiarization process (7). For externally recruited/internally transferred designers, there is a time period for recruiting/inducting (8)

$$
\begin{gathered}
d / d t \text { (New_Designers) }=\text { Desnrs_Recr } \\
\text { - New_Dgnrs_Gng_Exp }
\end{gathered}
$$

New_Designers $=0$ (initial value is 0 )

Desnrs_Recr $=($ Desnrs_Shortfall

$$
\text { - Desnr_Pos_Ind)/Time_to_Rec. }
$$

The model allows a time period for the training or familiarization of designers. The model recognizes that there are different time periods required for each of these designers, which, in turn, affects its efficiency estimation.

\section{APPENDIX B}

The questions used for an interview were used to determine the cause of a rework event. Identification and determination of rework adopted the following process:

1) Identify the amount of rework being experienced on-site, i.e., redesigns, nonconformances, etc. What effect has the rework had on project cost and program?
2) Identify an event to be examined and gain an understanding on the possible ramifications the event has had on project participants. Informal conversations with the contractor should provide an overview of the situation to be studied.

3) Identify the project participants involved.

4) Contact each participant and ask for their assistance in the research. Arrange a time to see them. Preferably when it is convenient for them.

5) At the interview, explain the reason for the research, specifically highlighting their importance. Briefly explain the situation that you want the interviewee to talk about.

6) Ask the interviewee to list those events that occurred in sequence.

7) Ask the interviewee to identify any unexpected events. If particular unexpected events occurred, try asking the following questions:

i) Why do you think this event(s) happened?

ii) Why do you think they were not predicted?

iii) Would it have been possible to predict them?

iv) If so, how should you have predicted them? And on what basis?

8) If the interviewee suggests these events were unpredictable, possibly ask the following questions:

9) Why were they unpredictable?

10) What do you see as the key problems that have arisen from the project?

11) How do you think these problems have affected other project participants?

12) List the problems. Then, ask the following questions for each problem:

i) Could this problem have been prevented?

ii) Were any steps taken to prevent the rework before it occurred?

iii) If so, what and by whom?

iv) Did the attempts to solve the problem fail or were they partially successful?

v) In either case, why?

vi) Is there anything anyone else could have done that would have solved/eliminated this problem? If so, what? Whom? Why was it not done?

13) Conclude the interview by asking some general questions and ask the interviewee for suggestion(s) on how might the current situation been avoided.

\section{ACKNOWLEDGMENT}

The authors would like to thank the contracting organization and other project team members involved in the case study for their cooperation throughout the study. The reviews of the Associate Editor, Prof. J. K. Pinto, and three anonymous referees were very constructive and extremely helpful.

\section{REFERENCES}

[1] H. Abdul-Rahman, "The Management and Cost of Quality for Civil Engineering Projects,” Ph.D. dissertation, Univ. Manchester Inst. Sci. Technol. (UMIST), Manchester, U.K., 1993. 
[2] T. K. Abdul-Hamid and S. E. Madnick, Software Project Dynamics. An Integrated Approach. Englewood Cliffs, NJ: Prentice Hall, 1991.

[3] F. Ackermann, C. Eden, and T. Williams, "Modeling litigation: Mixing qualitative and quantitative approaches," Interfaces, vol. 27, no. 2, pp. 4865, 1997.

[4] S. Andi and T. Minato, "Representing causal mechanism of defective designs: A system approach considering human errors," Constr. Manage. Econ., vol. 21, no. 8, pp. 297-305, 2003.

[5] S. Andi and T. Minato, "Representing causal mechanism of defective designs: Exploration through case studies," Constr. Manage. Econ., vol. 22, no. 1, pp. 183-192, 2004.

[6] A. Atkinson, "Human error in the management of building projects," Constr. Manage. Econ., vol. 16, pp. 339-349, 1998.

[7] E. Banset and G. M. Parsons, "Communication failure in Hyatt Regency Disaster,” ASCE J. Prof. Issues Eng., vol. 115, no. 3, pp. 273-288, 1989.

[8] H. A. Bashir and V. Thomson, "Models for estimating design effort and time," Des. Stud., vol. 22, pp. 141-155, 2001.

[9] T. Betsch, S. Haberstroh, and C. Höhle, "Explaining routinized decisionmaking: A review of theories and model," Theory Psychol., vol. 12, pp. 453-488, 2002.

[10] T. Betsch, S. Haberstroh, B. Molter, and A. Glöckner, "Oops, I did it again-relapse errors in routinized decision-making," Org. Behav. Hum. Decis. Process., vol. 93, pp. 62-74, 2004.

[11] D. Blockley, "Analysis of structural failures," in Proc. Inst. Civil Eng. Part 1, 1977, vol. 62, pp. 51-74.

[12] C. B. Brown and X. Yin, "Errors in structural engineering," ASCE J. Struct. Eng., vol. 114, pp. 2575-2593, 1988.

[13] J. L. Burati, J. J. Farrington, and W. B. Ledbetter, "Causes of quality deviations in design and construction," ASCE J. Constr. Eng. Manage., vol. 118, no. 1, pp. 34-49, 1992.

[14] J. S. Busby, "Error and distributed cognition in design," Des. Stud., vol. 22, pp. 233-254, 2001.

[15] M. D. Cohen, J. March, and J. P. Olsen, "A garbage can model of organizational choice," Adm. Sci. Quart., vol. 17, pp. 1-25, 1972.

[16] K. G. Cooper, "Naval shipyard production: A claim settled and a framework built," Interfaces, vol. 10, no. 6, pp. 30-36, 1980.

[17] K. G. Cooper, "The rework cycle: Benchmarking for the project manager," Proj. Manage. J., vol. 24, no. 1, pp. 17-22, 1993.

[18] I. D. Cox, J. Morris, J. H. Rogerson, and G. E. Jared, "A quantitative study of post contract award design changes in construction," Constr. Manage. Econ., vol. 17, no. 4, pp. 427-439, 1999.

[19] S. Christodoulou, F. H. Griffis, L. Barrett, and M. Okungbowa, "Qualification based selection of professional A/E services," ASCE J. Manage. Eng., vol. 20, no. 2, pp. 34-41, 2004.

[20] S. Chritamara, S. O. Ogunlana, and N. N. Bach, "Investigating the effect of initial scope establishment on the performance of a project through system dynamics modelling," Eng., Constr. Arch. Manage., vol. 8, pp. 381-392, 2001.

[21] S. Chritamara, S. O. Ogunlana, and N. N. Bach, "System dynamics modelling of design and build projects," Constr. Innov., vol. 2, pp. 269-295, 2002.

[22] R. M. Cyert and J. G. March, A Behavioural Theory of the Firm, 2nd ed. Cambridge, U.K.: Blackwell, 1992.

[23] B. Czarniawska-Joerges, Ideological Control in Nonideological Organizations. New York: Praeger, 1988.

[24] W. P. S. Dais and D. Blockley, "Galileo's confirmation of a false hypothesis: A paradigm of logical error in design," Civil Eng. Syst., vol. 11, pp. 75-77, 1994.

[25] J. A. De Lapp, D. N. Ford, J. A. Bryant, and J. Horlen, "Impacts of CAD on design realization," Eng., Constr. Arch. Manage., vol. 11, no. 4, pp. 284-291, 2004.

[26] E. W. East, J. G. Kirby, and G. Perez, "Improved design review through Web collaboration," ASCE J. Manage. Eng., vol. 20, no. 2, pp. 51-57, 2004.

[27] C. Eden, T. Williams, and S. Howick, "The role of feedback dynamics in disruption and delay on the nature of disruption and delay (D\&D) in major projects," J. Oper. Res. Soc., vol. 51, no. 3, pp. 291-300, 2000.

[28] J. J. Farrington, "A methodology to identify and categorize costs of quality deviations in design and construction," Ph.D. dissertation, Grad. Sch., Clemson Univ., Clemson, SC, 1987.

[29] R. Graham. (2004, July 7). Paris accident probe focuses on ceiling struts. Financ. Times [Online]. Available: http://news.ft/com

[30] C. Grey and W. Hughes, Building Design Management. Oxford, U.K.: Butterworth Heinemann, 2001.
[31] E. Hagan and G. Mays, "Human factors engineering in the US nuclear arena," Nucl. Safety, vol. 22, pp. 337-346, 1981.

[32] W. T., Hester, J. A. Kuprenas, and T. C. Chang, Construction Changes and Change Orders: Their Magnitude and Impact, Source Document 66, Constr. Ind. Inst., Univ. Texas, Austin, 1991.

[33] G. M. Hoedemaker, J. D. Blackburn, and L. N. Van Wassenhove, "Limits to concurreny," Decis. Sci., vol. 30, no. 1, pp. 1-17, 1999.

[34] N. W. Hurst, L. J. Bellamy, T. A. W. Geyer, and J. A. Astley, "A classification scheme for pipework failures to include human and socio-technical errors and their contribution to pipework failure frequencies," J. Hazard. Mater., vol. 26, pp. 159-186, 1991.

[35] W. James, The Principles of Psychology, vol. 1. New York: Dover, 1890.

[36] S. A. Jensen, "Can project dynamics be modelled?," in Proc. 1988, Int. Conf. Syst. Dyn. Soc., Albany, NY, 1988, pp. 171-187.

[37] D. Kaminetzky, Design and Construction Failures: Lessons from Forensic Investigations. New York: McGraw-Hill, 1991.

[38] T. Keltz, An Engineers View of Human Error. Rugby, U.K.: Institution of Chemical Engineers, 1985.

[39] B. Lawson, How Designers Think. London, U.K.: Butterworth Architecture, 1980.

[40] P. E. D. Love, P. Mandal, and H. Li, "Determining the causal structure of rework in construction projects," Constr. Manage. Econ., vol. 17, no. 4, pp. 505-517, 1999.

[41] P. E. D. Love, H. Li, and P. Mandal, "Rework: A symptom of a dysfunctional supply chain,” Eur. J. Purch. Supply Manage., vol. 5, no. 1, pp. 1-11, 1999.

[42] P. E. D. Love and H. Li, "Quantifying the causes and costs of rework in construction," Constr. Manage. Econ., vol. 18, no. 4, pp. 479-490, 2000.

[43] P. E. D. Love, "Influence of project type and procurement method on rework costs in building construction projects," ASCE J. Constr. Eng. Manage., vol. 128, no. 1, pp. 18-29, 2002.

[44] P. E. D. Love, L. Y. Shen, H. Li, G. D. Holt, and Z. Irani, "Using system dynamics to understand change and rework within construction project management systems," Int. J. Proj. Manage., vol. 20, no. 6, pp. 425-436, 2002.

[45] P. E. D. Love, Z. Irani, and D. Edwards, "Learning to reduce rework in projects: Analysis of firms learning and quality practices," Proj. Manage. $J .$, vol. 34, no. 3, pp. 13-25, 2003.

[46] P. E. D. Love, Z. Irani, and D. J. Edwards, "A rework reduction model for construction projects," IEEE Trans. Eng. Manage., vol. 51, no. 4, pp. 426-440, Nov. 2004.

[47] P. E. D. Love and P.-E. Josephson, "Role of the error-recovery process in projects," ASCE J. Manage. Eng., vol. 20, no. 2, pp. 70-79, 2004.

[48] R. A. Lundin and A. Söderham, "A theory of the temporary organization," Scand. J. Manage., vol. 11, no. 4, pp. 437-455, 1995.

[49] G. McMaster, "Can we learn from project histories?," PM Netw., vol. 14, no. 7, pp. 66-67, 2000

[50] M. B. Miles and A. M. Huberman, Qualitative Data Analysis-A Source book of New Methods. Newbury Park, CA: Sage, 1984.

[51] E. J. Miller and A. K. Rice, Systems of Organization: The Control of Task and Sentient Boundaries. $\quad$ London, U.K.: Tavistock Inst., 1967.

[52] R. E. Melchers, "Human error in structural design tasks," ASCE J. Struct. Eng., vol. 115, no. 7, pp. 1795-1807, 1989.

[53] K.-O. Nylén, "Cost of failure in a major civil engineering project," Licentiate Thesis, Div. Constr. Manage. Econ., Dept. Real Estate Constr. Manage., Royal Inst. Technol., Stockholm, Sweden, 1996.

[54] S. Ogunlana, J. Lim, and K. Saeed, "DESMAN: A dynamic model for managing civil engineering design projects," Comput. Struct., vol. 76, pp. 401-419, 1998 .

[55] D. Orndoff, "Errors and omissions: Fertile ground for high costs," Mil. Eng., vol. 506, pp. 107-109, 1986.

[56] B. J. Palisi, "Some suggestions about the transitory-permanence dimension of organization," Br. J. Sociol., vol. 21, pp. 200-206, 1970.

[57] F. Pena-Mora and M. Park, "Dynamic planning for fast tracking building construction projects," ASCE J. Constr. Eng. Manage., vol. 127, no. 6, pp. 445-456, 2001.

[58] W. Pena, Problem Seeking: An Architectural Programming Primer. Boston, MA: Cahner Books International, 1977.

[59] H. Petroski, Design Paradigms-Case Histories of Error and Judgement in Engineering. Cambridge, U.K.: Cambridge Univ. Press, 1985.

[60] A. Pressman, Architecture 101: A Guide to the Design Studio. New York: Wiley, 1993.

[61] J. Reason, Human Error. Cambridge, U.K.: Cambridge Univ. Press, 1990. 
[62] J. Reason, "Human error: Models and management," West. J. Med., vol. 172, no. 6, pp. 393-396, 2000.

[63] G. P. Richardson and A. L. Pugh III, Introduction to System Dynamics Modelling. Cambridge, MA: MIT Press, 1981.

[64] C. Robson, Real World Research: A Resource for Social Scientists and Practitioner-Researchers. Oxford, U.K.: Blackwell, 1993.

[65] A. G. Rodrigues and J. Bowers, "System dynamics in project management: A comparative analysis with traditional methods," Syst. Dyn. Rev., vol. 12, no. 2, pp. 121-139, 1996

[66] G. Rounce, "Quality, waste, and cost in architectural and building design management," Int. J. Proj. Manage., vol. 16, no. 2, pp. 123-127, 1998.

[67] K. Saeed and K. Brook, "Contact design for profitability in macroengineering projects," Syst. Dyn. Rev., vol. 12, no. 3, pp. 235-246, 1996.

[68] G. F. Sowers, "Human factors in civil and geotechnical engineering failures," ASCE J. Geotech. Eng., vol. 119, no. 2, pp. 238-256, 1993.

[69] J. D. Sterman, Systems Dynamics Modeling for Project Management, Systems Dynamics Group, Sloan School of Management, MIT, Cambridge, MA, 1992.

[70] M. G. Stewart and R. E. Melchers, "Checking models in structural design," ASCE J. Struct. Eng., vol. 115, no. 6, pp. 1309-1324, 1989.

[71] P.-O. Svelinger, Organisatorisk samordning vid projektering (Organisational coordination in the design phase), Rep. 44, Inst. byggnadsekonomi och byggnadsoganisation, Chalmers techiska högskola, Göteborg, Sweden, 1996.

[72] P. A. Tilley and S. L. McFallan, Design and Documentation Quality Survey Designers' Perspectives, presented at the CSIRO Build. Constr. Eng., Melbourne, Australia, 2000.

[73] D. Wantanakorn, M. J. Mawdesley, and W. H. Askew, "Management errors in construction," Eng. Constr. Arch. Manage., vol. 6, no. 2, pp. 112-120, 1999.

[74] T. H. Willis and W. D. Willis, "A quality performance management system for industrial construction engineering projects," Int. J. Qual. Rel. Manage., vol. 13, no. 9, pp. 38-48, 1996.

[75] T. M. Williams, C. Eden, F. Ackermann, and A. Tait, "The effects of design changes and delays on project costs," J. Oper. Res. Soc., vol. 46, no. 7, pp. 809-818, 1995.

[76] T. M. Williams, C. Eden, F. Ackermann, and A. Tait, "Vicious circles of parallelism," Int. J. Proj. Manage., vol. 13, no. 3, pp. 151-155, 1995.

[77] E. F. Wolstenholme, System Inquiry. Chichester, U.K.: Wiley, 1990.

[78] A. Zeitoun and G. Oberlander, Early Warning Signs of Project Changes, Source Document 91, Constr. Ind. Inst., Univ. Texas, Austin, 1993.

[79] J. Zeisel, Inquiry by Design. Cambridge, U.K: Cambridge Univ. Press, 1984.

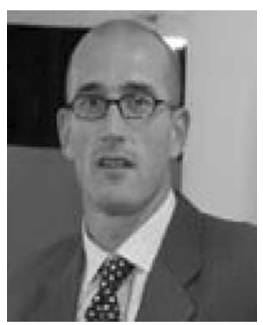

Peter E. D. Love received the M.Sc. degree in construction management from the University of Bath, Bath, U.K., and the Ph.D. degree in operations management from Monash University, Melbourne, Australia.

$\mathrm{He}$ is the inaugural Chair of Construction Innovation in the Department of Construction Management, Curtin University of Technology, Bentley, Australia. He has a multidisciplinary background. He is the author or coauthor of over 300 internationally refereed research papers that have appeared in leading international journals such as the Journal of Management Information Systems, European Journal of Operational Research, Information and Management, Information and Organization, European Journal of Information Systems, IEEE TRANSACTIONS ON ENGINEERING MANAGEMENT, International Journal of Production Economics, and International Journal of Production Research. His current research interests include project management, engineering forensics, operations management, and information systems evaluation.

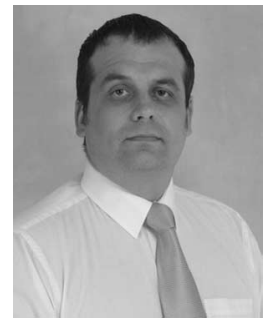

David J. Edwards received the B.Sc. (Hons) and Ph.D. degrees from the University of Wolverhampton, Wolverhampton, U.K.

$\mathrm{He}$ is currently with the Off-Highway Plant and Equipment Research Centre, Department of Building and Civil Engineering, Loughborough University, Loughborough, U.K. He is a Peer Referee for the Health and Safety Executive; and a member of the U.K. Home Office's Plant Theft Action Group. Since 2000, he has secured more than $£ 1000000$ of research funding. In 2005, he launched the HandArm Vibration Test Centre (HAVTEC) to mitigate the health risk associated with operating power tools. HAVTEC currently has over 12000 registered users. $\mathrm{He}$ is the author or coauthor of more than 100 peer-reviewed research papers, 14 textbooks, two textbook chapters, and three digital versatile disks. He is on the technical and editorial panels of several international conferences and is a Peer Referee for 18 academic journals in his field. He is also a Peer Referee for the Qualifications and Curriculum Authority, the Health and Safety Executive, the EPSRC, the U.K. Ministry of Defence, the Major Contractors Group, the Major Hire Companies Group, and the National Research Foundation (South Africa) His current research interests include plant and maintenance management, occupational health and safety, and project management.

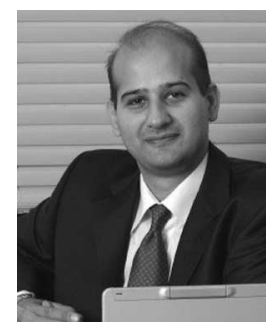

Zahir Irani received the B.Sc. (Hons) and Master's of Philosophy degrees from the University of Salford, Salford, Greater Manchester, U.K., and the Ph.D. degree from Brunel University, London, U.K. He is currently the Head of the Brunel Business School, Brunel University, Uxbridge, U.K.

$\mathrm{He}$ is the Hooker Distinguished Professor at McMaster University, Hamilton, ON, Canada, as well as a Visiting Professor at several universities. He leads a multidisciplinary group of international Ph.D. students engaged in research on information systems evaluation and application integration. He is the Editor-in-Chief of the established Journal of Enterprise Information Management and the European Editor of the Business Process Management Journal. He is the author or coauthor of more than 300 internationally refereed research papers that have appeared in leading international journals such as the Journal of Management Information Systems, European Journal of Operational Research, Information and Management, Information and Organization, European Journal of Information Systems, IEEE TRANSACTIONS ON ENGINEERING MANAGEMENT, International Journal of Production Economics, and International Journal of Production Research His current research interests include information systems evaluation, transformational government, enterprise management, and project management. 